\title{
Wild Musa Species Collection of Purwodadi Botanic Garden: Inventory and Its Morpho-taxonomic Review
}

\author{
Lia Hapsari ${ }^{*}$
}

\author{
${ }^{1}$ Purwodadi Botanic Garden - Indonesian Institute of Sciences, Pasuruan
}

\begin{abstract}
Indonesia, being part of the center of origin of bananas (Musaceae), has a large number diversity of bananas both wild seeded species and edible seedless cultivated varieties. Inventory of wild Musa species in Purwodadi Botanic Garden has been conducted through compiling data records from PBG's Registration section, field inspection and observation to living collections in the garden, herbarium specimens and literature studies. The results show that total 17 wild Musa accessions has been recorded planted in Purwodadi Botanic Garden since 1990 until 2012; comprises of 8 Musa acuminata sub species, 2 Musa balbisiana forms, 1 Musa ornata, 1 Musa troglodytarum, 1 Musa borneensis and 4 unidentified species Musa spp.; but only 8 living accessions remained in 2012. Morpho-taxonomic review of those 8 wild Musa accessions remained will be discussed in this paper including their geographical distributions. According to its differentiated morphological characteristics observations, it is known that there are three accessions were resembled cultivars and one unidentified species have been determined its species level, so that their registration identity needs to be revised. It is important next to prioritize ex-situ conservation of wild Musa species not yet collected in Purwodadi Botanic Garden especially from Eastern Indonesia.
\end{abstract}

Keywords: : inventory, morphological characteristic, wild species, Musa, Purwodadi Botanic Garden

\section{INTRODUCTION}

Indo-Malesian region is considered as the main center origin and diversity of bananas (Musaceae) [1, 2, 3). Indonesia, being part of the center of origin, has a large number of bananas both edible seedless bananas and wild seeded bananas. Edible seedless bananas mostly grown in the backyards or home gardens whereas wild seeded bananas commonly found in the wild [4]. The genus Musa are generally grouped into four sections: Australimusa $(n=10)$, Callimusa $(n=10)$, Rhodochlamys $(\mathrm{n}=11)$ and Eumusa $(\mathrm{n}=11)[5,6$, 7, 8]. Most members of Callimusa and Rhodoclamys are ornamentals in nature; they originated on the Asian continent. Australimusa has 5-6 species, but most important are fibres yielding Musa textilis and fruits yielding Musa fehi, they distribute mostly in Southeast Asia and Pasific

\footnotetext{
${ }^{*}$ Corresponding Author:

Lia Hapsari

Purwodadi Botanic Garden - Indonesian Institute of Sciences, Pasuruan, Indonesia

Email : lia.hapsari@lipi.go.id; hapsari.lia@gmail.com
}

Islands. Eumusa widely distributed in Asia, Africa and South America [9]. One more section Ingentimusa ( $\mathrm{n}=7$ ), comprised of single species Musa ingens Simmonds [10].

In 90's Purwodadi Botanic Garden was the leading botanic garden of its Musaceae collection in South East Asia. The collection reached over 166 numbers, including species, varieties and/or cultivated varieties (mostly cultivated varieties) which were collected through explorations, plants exchanging, grants, community or personal contribution, etc. The first Musa collection was recorded in 1972 [11]. In 2010, its Musa collections there were as many as 119 accessions, 230 specimens, consists of 9 wild species and 110 cultivars [12]. Then by field inspection in early 2012 it decreased become 103 accessions, 197 specimens, 8 wild types and 95 cultivars [13]. These valuable germplasm banks supposed to supply information and propagation materials in support of banana improvement projects of the national research and development systems. Further conservation efforts; an effective monitoring and cultivation management strategy are required to keep this 
Musa germplasms continuously conserved and preserved for future.

The potential uses of wild seeded banana species has not been much explored yet in Indonesia, it is supposed to be linked to its role as germplasms materials for further banana improvements. A vital part of any plant improvement program is the assemblage of germplasm materials that provide sources for resistance genes. The favourite donors are the wild relatives that thrive under adverse conditions. If and when a better variety needs to be improved, the variability will be needed and should be collected, evaluated and used [3, 4, 14]. This paper presents inventory, taxonomic review and differentiating morphological characters of 8 wild Musa species living accessions collection of Purwodadi Botanic Garden including its geographical distributions.

\section{MATERIALS AND METHODS}

The study was conducted at Musa germplasm plots collection of Purwodadi Botanic Garden Indonesian Institute of Sciences at Area II Vak XXIVA-B-D-E. It is located in a low land dry area of Pasuruan District about $65 \mathrm{~km}$ south of Surabaya, East Java, at an altitude of $300 \mathrm{~m}$ above sea level, vertisol soil type with the average rainfall about $2366 \mathrm{~mm}$ per year.

Inventory of wild Musa species records in Purwodadi Botanic Garden were conducted by compiling datas from catalogues records, exploration technical reports, plant collections receipt book and other manuscripts from PBG's registration section also from PBG's herbarium records. The datas compiled including its origins and habitats where the collections were collected including their geographical distributions from references.

Description as well as measurements of the wild Musa species living specimens in Purwodadi Botanic Garden were observed and characterized using 'Descriptors for Banana (Musa spp.)' published by IPGRI-INIBAP/CIRAD (1996) [15] also documented taken by digital camera. Its differentiating morphological characteristics obtained from field observations then matched with references also herbarium specimens to ascertain its types.

Study to Musa herbarium materials were conducted on its particular 'type' species in the Herbarium Bogoriense (BO), Central for Re-search and Development for Biology, Bogor. Some relevant particular Musa specimens col-lection of Bogor Botanic Garden were also studied. Some observations and herbarium re-cords have been clearly listed and all those re-ferences are cited where relevant to particular species.

\section{RESULTS AND DISCUSSION}

Purwodadi Botanic Garden has been col-lecting Musa germplasms for more than two decades both wild species and cultivated varieties (mostly cultivars). Field inspections on October 2010, its collection remain 111 accessions com-prises of 8 numbers of wild species and 103 cul-tivars. The lost of accessions mostly due to abiotic (drought) and biotic (banana wilts and bunchy top disease) stresses on field [11, 12]. Accessions lost caused by diseases were tendency experienced in banana cultivars than wild spe-cies. Wild accessions lost mostly caused by abi-otic than biotic stresses. Wild Musa species are tending to be more resistant to such diseases, that's what make studies of wild Musa species becoming important. Breeding of banana culti-vars to some particular wild Musa species have resulted some resistant and superior banana clones [1, 4].

\section{Inventory of wild Musa species in Purwodadi Botanic Garden}

There are about 37 to 45 species of Musa in the world. They are mostly confined to India, Assam, Srilanka, Burma, Thailand, Vietnam, Chi-na, probably Japan, Malaysia, Indonesia, Philip-pines, Papua New Guinea, and Northern part of Australia. In Indonesia alone, there are probably about 9 to 11 Musa species [4]. Several plants collecting missions has been conducted by Purwodadi Botanic Garden to ex-situ conserved plants including Musa specimens both wild species and native/indigenous unique cultivars espescially from Eastern Indonesia.

Records result shows that Purwodadi Botanic Garden have collected and planted 17 accessions of wild Musa species since 1990 until today. It comprises of 8 accessions of Musa acuminata sub species, 2 accessions of Musa balbisiana forms, 1 accession of Musa ornata, 1 accession of Musa troglodytarum, 1 accession of Musa borneensis and 4 accessions of unidentified Musa species. By re-cent direct field inspections in June 2012 noted that there are only 8 living accessions remained (Table 1) which will be reviewed its morpho-taxonomic later.

Musa ornata, Musa troglodytarum and Musa borneensis recorded has been collected in the garden during 1990-2010 (Table 1). Here are short morpho-taxonomic reviews about them: 
Table 1. Inventory list of wild Musa species in Purwodadi Botanic Garden

\begin{tabular}{|c|c|c|c|c|c|}
\hline No. & Location & Spesies & Vernacular name & Origin & Year \\
\hline 1 & XXIV.E.40-a & $\begin{array}{l}\text { M. acuminata var. } \\
\text { flava }\end{array}$ & P. Jantung Kuning & Tuban, East Java & 1990-1999-2007-2010-now \\
\hline 2 & XXIV.E.18-ab & $\begin{array}{l}\text { M. acuminata var. } \\
\text { rutilifes }\end{array}$ & P. Cici Alas & $\begin{array}{l}\text { Pasuruan, East } \\
\text { Java }\end{array}$ & 1990-1999 \\
\hline 3 & XXIV.D.27 & $\begin{array}{l}\text { M. acuminata var. } \\
\text { rutilifes }\end{array}$ & P. Cici Alas & $\begin{array}{l}\text { Sumba, Lesser } \\
\text { Sunda Islands }\end{array}$ & 1990-1999-2007-2010-now \\
\hline 4 & XXIV.D.30-a & $\begin{array}{l}\text { M. acuminata var. } \\
\text { rutilifes }\end{array}$ & P. Cici Alas & $\begin{array}{l}\text { Sumba, Lesser } \\
\text { Sunda Islands }\end{array}$ & 1990-1999-2007-2010-now \\
\hline 5 & XXIV.E.33-a & $\begin{array}{l}\text { M. acuminata var. } \\
\text { rutilifes }\end{array}$ & P. Cici Alas & East Java & 1990-1999-2007-2010 \\
\hline 6 & V.D.II.1-a & $\begin{array}{l}\text { M. acuminata var. } \\
\text { rutilifes }\end{array}$ & P. Cici Alas & East Java & 1990-1999-2007 \\
\hline 7 & XXIV.D.12-a & $\begin{array}{l}\text { M. acuminata var. } \\
\text { rutilifes }\end{array}$ & P. Cici Alas & East Java & 1990-1999-2007-2010-now \\
\hline 8 & XXIV.D.26-a & $\begin{array}{l}\text { M. acuminata var. } \\
\text { tomentosa }\end{array}$ & Unti Darek & $\begin{array}{l}\text { South East } \\
\text { Sulawesi }\end{array}$ & 1990-1999-2007-2010-now \\
\hline 9 & XXIV.D.1-abc & M. balbisiana & Klutuk Ijo & $\begin{array}{l}\text { Pasuruan, East } \\
\text { Java }\end{array}$ & 1990-1999-2007-2010-now \\
\hline 10 & XXIV.B.19 & M. balbisiana & Klutuk Wulung & Central Java & 1990-1999-2007-2010-now \\
\hline 11 & V.D.II.2-a & M. ornata & P. Hias & East Java & 1990 \\
\hline 12 & XXIV.D.49 & M. troglodytarum & $\begin{array}{l}\text { P. Tongkat Langit, } \\
\text { P. Cungit }\end{array}$ & East Java & 1999 \\
\hline 13 & XXIV.E.66-a & M. borneensis & $\begin{array}{l}\text { P.Unkaok, } P . \\
\text { Unkadan }\end{array}$ & $\begin{array}{l}\text { Kutai Barat, East } \\
\text { Kalimantan }\end{array}$ & 2010 \\
\hline 14 & XXIV.A.27 & Musa sp. & Not available & $\begin{array}{l}\text { Solok, West } \\
\text { Sumatra }\end{array}$ & 2010-now \\
\hline 15 & XXIV.A.28 & Musa sp. & Not available & $\begin{array}{l}\text { TN. Bukit } \\
\text { Barisan, Bengkulu }\end{array}$ & 2010 \\
\hline 16 & XXIV.B.26 & Musa sp. & Not available & $\begin{array}{l}\text { Buru Island, } \\
\text { Maluku }\end{array}$ & 2010 \\
\hline 17 & XXIV.A.29 & Musa sp. & Not available & $\begin{array}{l}\text { CA. Gunung } \\
\text { Kentawan, } \\
\text { South Kalimantan }\end{array}$ & 2010 \\
\hline
\end{tabular}

\section{Musa ornata Roxb.}

Synonims: Musa mexicana Matuda, Musa speciosa Ten., Musa troglodytarum var. rubrifolia Kuntze. Section: Rhodochlamys. Characteristics: Pseudostem slender, 1-3m; leaves oblong or lanceolate from an obtuse or rounded base, green, tinged with violet on the underside of the costa, $60-200 \mathrm{~cm}$ by $18-27 \mathrm{~cm}$. Bracts bright violet with a yellowish top, erect peduncle (Figure 1-a). Geographic distributions: Native to South West Asia, Northern India, South India, Himalaya, Myanmar; widespread in cultivation, in Java cul-tivated as an ornamental at $0-1500 \mathrm{~m}$ above sea level $[9,14,16,17,18]$.

\section{Musa troglodytarum $L$.}

Synonims: Musa fehi Bertero ex Vieillard, Mus. seemanni Mueller, M. uranoscopos Miguel. Section: Australimusa. Characteristics: Spurious stem up to $5 \mathrm{~m}$ long; leave light-or dark green, not strongly tillering. Male bud well-developed, fruiting raceme erect or almost. Sap color red- purple to purple. Fruits large, pulp color ranges from yellow to orange brick-red or red brown, seeds at most 6 , often absent, black or brown (Figure 1-b). Geographic distributions: Introduces from the Moluccas, New Guinea, and the Pasific Islands. It distributed throughout the Pacific region, in Indonesia and Polynesia; in Java locally cultivated $[16,18,19]$.

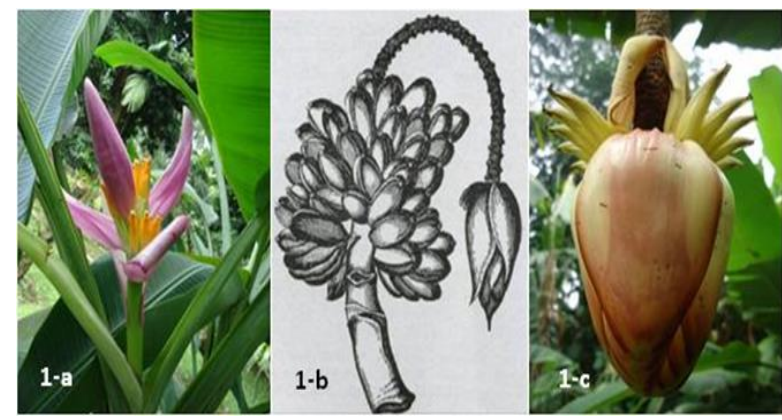

Figure 1 Inflorescence of Musa ornata collection of Bogor Botanic Garden (a), Musa tlogodytarum 'type' [Rumphius (1763) in Häkkinen, Väre and Christenhusz (2012)] and male bud of Musa borneensis collection of Bogor Botanic Garden (c) 


\section{M. borneensis Becc.}

No synonyms are recorded. Section: Callimusa. Characteristics: A medium sized species, with den-sely clustering, slender pseudostems to $3.5 \mathrm{~m}$ (12 ft.) tall. The broad corrugated auricles at the region where the petiole joins the sheath are conspicuous and characteristic. Inflores-cence horizontally held and later pendulous, with varies bract colors from yellow, greenish, pale violet to red-purple. Male bud in advanced bloo-ming is very broadly ovate, with the bracts strongly imbricate. Fruit glabrous, uni-seriate, $14-16 \mathrm{~cm}$. long and $3.5 \mathrm{~cm}$. thick, completely filled with seeds surrounded by very little pulp (Figure 1-c). Geographic distributions: from the tropical lowlands of southern Sarawak on the island of Borneo [18, 19, 20, 21].

\section{Morpho-taxonomic review of 8 living wild Musa accessions}

Through observations to its differentiating morphological characteristics of those 8 living Musa specimens revealed that some of them are not true to its type and one species has been determined its species level so that their registration identity needs to be revised by proposing the D6 forms in PBG's Registration section. Accessions number XXIV.D. 26-a (Figure 2-a) was not true to Musa acuminata var. tomentosa, while XXIV.D.27 (Figure 2-b) and XXIV.D.30-a (Figure 2-c) were not true to Musa acuminata var. rutilifes, their differentiating morphological characteristics were resembled Musa acuminata cultivars, the most prominent is their seedless fruits. Edibility of mature fruits of diploid Musa acuminata cultivars (AA) came about as a result of female fertility and parthenocarpy, and such edible types would no doubt have been selected and maintained by humans. Triploid AAA cultivars arose from these diploids, perhaps following crosses between edible diploids and wild Musa acuminata subspecies, giving rise to a wide range of AAA genotypes [23].

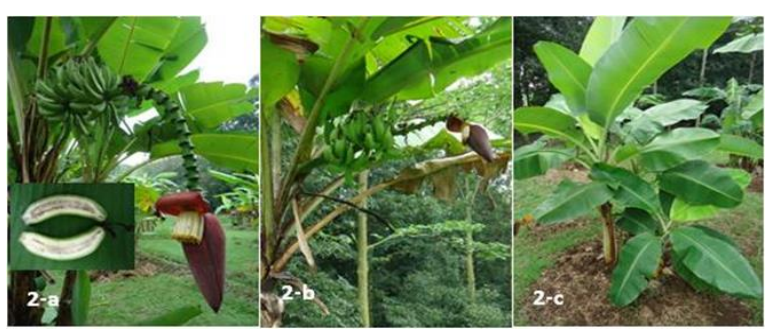

Figure 2 Inflorescence and seedless fruit of XXIV.D. 26-a (a), Inflorescence of XXIV.D.27 (b) and plant performance of XXIV.D.30-a (c). Those three accessions were resembled $M$. acuminata cultivars.

One unidentified spesies (Musa sp.) accession XXIV.A.27 have been determined its species level. Its morphological characteristics quite close resembled to Musa acuminata var. alasensis (Figure 3a-d, Table 2-A). This accession was derived as a grant from Indonesian Tropical Fruit Research Institute Solok, West Sumatera in 2001 (P2001104). Musa acuminata is the most widespread of the Eumusa species being found throughout the range of the section as a whole. Chromosome structural changes, which have occurred spontaneously, or as a result of recombination events, have resulted in the development of natural reproductive barriers within the species, causing subspecies divergence and genetic diversity in the species as a whole [23]. There are about 15 varieties of Musa acuminata species in Indonesia; in Sumatera, five different populations have been successfully recognized; in Java, seven different populations, in Sulawesi one population; while in Molucca and Irian Jaya, only one population has been gathered. They can be found both in lowland and mountainous areas [4].

Characteristic features of Musa acuminata species are stems slender with varying development of brown markings; petiole margins erect or spreading; male bud like a top to ovoid, tip acute, purple, orange-red, yellow, or greenish yellow with lanceolate or narrowly ovate bracts; pollen grains many and fertile; fruits in two rows, cylindric or subcylindric with acuminate tip, pedicel shorts; seeds irregularly angulate-depressed, black when ripenned [1, 4]. Figure 3 and Table 2-A-B-C presents the differentiating morphological characteristics from field observations of Musa acuminata varieties of Purwodadi Botanic Garden including Musa acuminata var. alasensis (XXIV.A.27), Musa acuminata var. rutilifes (XXIV.D.12-a) and Musa acuminata var. flava (XXIV.E.40-a).

\section{Musa acuminata var, rutilifes (Back.) Nasution}

Characteristics: Medium clump, slender pseudostems with brown blotching without wax, short petioles and erect margins, yellowish green leaves and midrib. Male bud shapes like a top to ovoid with bracts purple-yellowish marking at base and few waxes. Fruits small, bottle necked tip, thin peels, yellowish pulp with many seeds (Table 2-b, Figure 3b-e-f).

Geographical distribution: Central and East Java, on open place or along stream, at 50-1500 m above sea level. In East Java, they are found abundantly in Jolo, at $600-700 \mathrm{~m}$ above sea level, it's near to where Purwodadi Botanic Garden lies [4, 14]. 

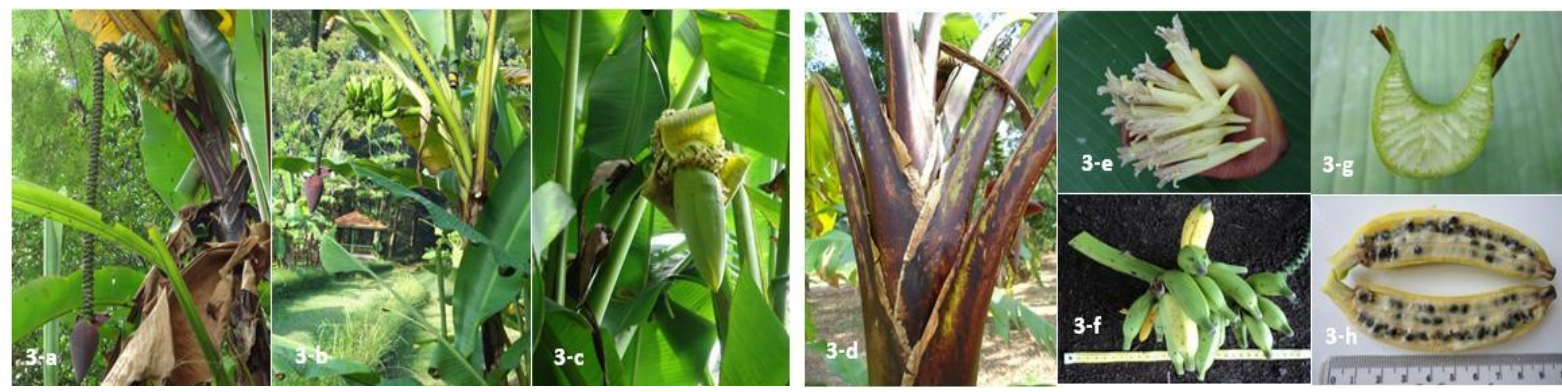

Figure 3. Morphological characteristics of Musa acuminata varieties: plant performance and inflorescence of Musa acuminata var. alasensis (a), Musa acuminata var. rutilifes (b), Musa acuminata var. flava (c); symmetrical insertion point of blades on petiole with extensive brown blotches at petioles base of M. acuminata var. alasensis (d); large shoulder bract with orange-red and discontinuing colour towards the base, and creamy male flowers with many fertile pollens of Musa acuminata var. rutilifes (e); bottle necked finger tips and yellow ripe fruits of M. acum inata var. rutilifes (f); open with margin spreading petiole canal leaf III of Musa acuminata var. flava (g). longitudinal section of bright yellow cracked ripe fruits Musa acuminata var. flava (h).

\section{Musa acuminata var. alasensis Nasution}

Characteristics: Extensive brown-dark brown blotching on pseudostems, glabroush peduncle, purplish brown petioles, margins wide and erect with pink midrib (Table 2-A, Figure 3-a-d).

Geographical distribution: growing wild at Alas canyon, Southeast Aceh, on open places along the road between Kotacane and Blangkejeran at 350-1300 m above sea level [4, 14]. Type specimens BO-1297622.

\section{Musa acuminata var. rutilifes (Back.) Nasution}

Characteristics: Medium clump, slender pseudostems with brown blotching without wax, short petioles and erect margins, yellowish green leaves and midrib. Male bud shapes like a top to ovoid with bracts purple-yellowish marking at base and few waxes. Fruits small, bottle necked tip, thin peels, yellowish pulp with many seeds (Table 2B, Figure 3-b-e-f).

Geographical distribution: Central and East Java, on open place or along stream, at 50-1500 $\mathrm{m}$ above sea level. In East Java, they are found abundantly in Jolo, at 600-700 m above sea level, it's near to where Purwodadi Botanic Garden lies $[4,14]$.

\section{Musa acuminata var. flava (Ridl.) Nasution}

Characteristics: Small to medium clump, pseudostems tall up to $4.7 \mathrm{~m}$ high with purplish brown to black blotching without wax. Petioles colour purplish brown blotching with wide erect margins and green midrib. Male bud shapes like a top to ovoid, bracts greenish yellow or yellow colour. Fruits medium, bright yellow peel colour, pulp yellowish with many seeds (Table 2C,Figure 3-c-g-h).
Geographical distribution: In open places, along the rivers or roads at 300-600 $\mathrm{m}$ above sea level, reported found in Central Kalimantan and Malay Peninsula also Pulau Tijau at Pahang River, Malaysia; whereas our collections originated from Tuban, East Java [4, 14, 24].

\section{Musa balbisiana Colla}

Characteristics: Herbs $4-6.5$ height; with robust pseudostem aspect, blotches slight or absent; petiole margin inclosed, not winged below or clasping pseudostem; peduncle perfectly glabroush; ovoid to rounded and imbricate male buds; bracts dark purple with a yellowish top obtuse, dull and waxy at least outside; male flowers variably flushed with pink, cream, pale yellow or pale pink and fruits full of seed berries crowded. It is sometimes cultivated for the leaves which are used for packing merchandise $[1,10,14,16$, 25]. Geographical distribution: widespread in Southeast Asia, considers it an introduction in Malaysia and Thailand $[1,10,14,23]$.

Musa balbisiana considered to be more drought and disease resistant than Musa acuminata, and such characteristics are often found in cultivars containing a 'B' genome [23]. Morpho-taxonomic classification of wild Musa balbisiana accessions has led to the identification of seeded BB clones. They are highly tolerant to BBTV, Panama wilt, leaf spot diseases [9].

Musa balbisiana in forms of Pisang Klutuk Ijo and Pisang Klutuk Wulung were mostly differentiated by their pseudostems, petioles and midrib colour, which is dark purple to black for Klutuk Wulung (Figure 4-a-b) while Klutuk Ijo is green (Figure 4-d-e-f). This is in accordance and reflected to their Javanese local names; 'Wulung' means 'Purple' whereas 'Ijo' means 'Green'. Differentiating morphological charac- 
teristics of these two forms of Musa balbisiana were presents on Figure 4 and Table 2-C-D.

Häkkinen already described 3 varieties of Musa balbisiana which he found during several expeditions to China and The Southeast Asia archipelagos i.e. bakeri, dechangensis, liukiuensis; some varieties descriptions still under works i.e. dadugaensis, tombiguangensis and some another undescribed varieties (Personal communications with Häkkinen, 2012). Musa balbisiana has exhibited a wide diversity which needs a classification up to subspecies level [9].
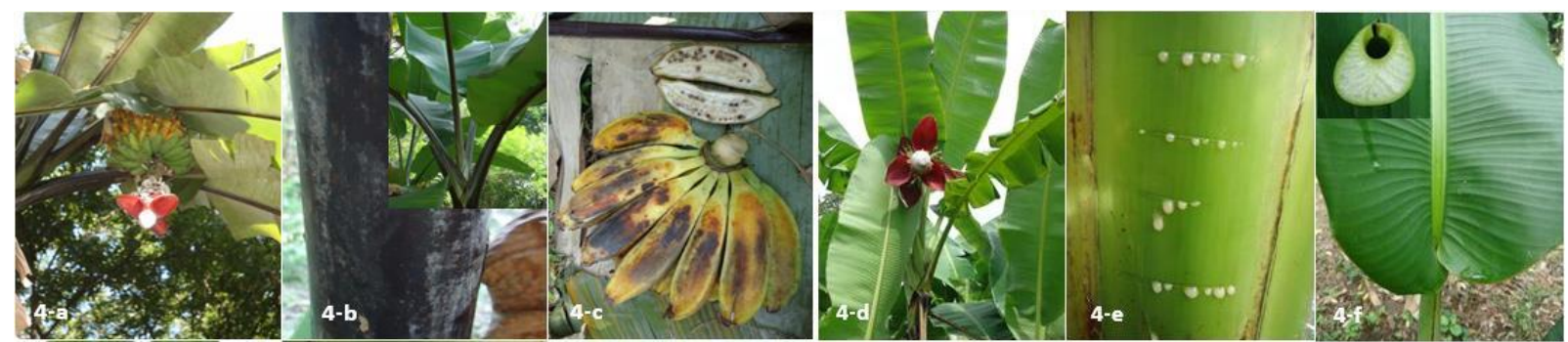

Figure 4. Morphologial characteristics of Musa balbisiana: plant performance and in florescence of Klutuk Wulung (a), waxyblack-dark purple colour pseudostem, petioles and leaves midribs of Klutuk Wulung (b), finger longitudinal section and ripe hand of Klutuk Wulung (c), plant performance and inflorescence of Klutuk Ijo (d) watery green pseudostem colour and milky sap of Klutuk Ijo (e), both side rounded leaf shape at base and margins overlapping petiole canal leaf III of Klutuk Ijo (f).

Table 2. Differentiating morphological characteristics of (A) M. acuminata var. alasensis, (B) M. acuminata var. rutilifes, (C) $M$. acuminata var. flava, (D) M. balbisiana (Klutuk Wulung) and (E) M. balbisiana (Klutuk Ijo).

\begin{tabular}{|c|c|c|c|c|c|}
\hline Description & $\begin{array}{l}\text { (A) } \\
\text { M. acuminata } \\
\text { var. alasensis }\end{array}$ & $\begin{array}{l}\text { (B) } \\
\text { M. acuminata } \\
\text { var. rutilifes }\end{array}$ & $\begin{array}{l}\text { (C) } \\
\text { M. acuminata } \\
\text { var. flava }\end{array}$ & $\begin{array}{l}\text { (D) } \\
\text { M. balbisiana } \\
\text { (Klutuk. Wulung) }\end{array}$ & $\begin{array}{l}\text { (E) } \\
\text { M. balbisiana } \\
\text { (Klutuk Ijo) }\end{array}$ \\
\hline Figure & $3-a-d$ & 3-b-e-f & $3-c-g-h$ & $4-a-c-d$ & $4-b-e-f$ \\
\hline Leaf habit & Intermediate & Erect & Intermediate & Intermediate & Intermediate \\
\hline Dwarfism & Normal & Normal & Normal & Normal & Normal \\
\hline Pseudostem height (m) & $2.1-2.9 \mathrm{~m}$ & $\leq 2 \mathrm{~m}$ & $\leq 2 \mathrm{~m}$ & $\geq 3 \mathrm{~m}($ up to $5 \mathrm{~m})$ & $\geq 3 \mathrm{~m}$ \\
\hline Pseudostem aspect & Slender & Slender & $\begin{array}{l}\text { Slender to } \\
\text { normal }\end{array}$ & Robust & Normal \\
\hline Pseudostem colour & Green-yellow & Green-yellow & Medium green & Black-dark purple & Green \\
\hline Pseudostem appearance & $\begin{array}{l}\text { Shiny (not } \\
\text { waxy) }\end{array}$ & $\begin{array}{l}\text { Shiny (not } \\
\text { waxy) }\end{array}$ & $\begin{array}{l}\text { Shiny (not } \\
\text { waxy) }\end{array}$ & Dull (waxy) & Dull (waxy) \\
\hline $\begin{array}{l}\text { Predominant underlying } \\
\text { colour of the seudostem }\end{array}$ & Cream & Light green & Watery green & Black-green & Watery green \\
\hline $\begin{array}{l}\text { Pigmentation of the un- } \\
\text { derlying pseudostem }\end{array}$ & Pink-purple & Pink-purple & Purple & Rusty brown & Pink-purple \\
\hline Sap colour & Pink-red & Milky & Milky & Milky & Milky \\
\hline Wax on leaf sheats & $\begin{array}{l}\text { Very little or } \\
\text { no visible sign } \\
\text { of wax }\end{array}$ & $\begin{array}{l}\text { Very little or } \\
\text { no visible } \\
\text { sign of wax }\end{array}$ & $\begin{array}{l}\text { Very little or } \\
\text { no visible sign } \\
\text { of wax }\end{array}$ & Very waxy & $\begin{array}{l}\text { Moderately } \\
\text { waxy }\end{array}$ \\
\hline Number of suckers & 2 & $2-5$ & $2-5$ & 3 to 6 & 3 to 6 \\
\hline Position of suckers & $\begin{array}{l}\text { Close to parent } \\
\text { (vertical } \\
\text { growth) }\end{array}$ & $\begin{array}{l}\text { Close to } \\
\text { parent } \\
\text { (vertical } \\
\text { growth) }\end{array}$ & $\begin{array}{l}\text { Close to parent } \\
\text { (vertical } \\
\text { growth) }\end{array}$ & $\begin{array}{l}\text { Close to parent } \\
\text { (vertical growth) }\end{array}$ & $\begin{array}{l}\text { Close to parent } \\
\text { (vertical } \\
\text { growth) }\end{array}$ \\
\hline Blotches at petiole base & $\begin{array}{l}\text { Extensive } \\
\text { pigmentation }\end{array}$ & $\begin{array}{l}\text { Large } \\
\text { blotches }\end{array}$ & Large blotches & $\begin{array}{l}\text { Extensive } \\
\text { pigmentation }\end{array}$ & $\begin{array}{l}\text { Without } \\
\text { pigmentation }\end{array}$ \\
\hline Blotches colour & $\begin{array}{l}\text { Brown to Dark } \\
\text { brown }\end{array}$ & Brown & Black-purple & Black-dark purple & $\begin{array}{l}\text { Without } \\
\text { pigmentation }\end{array}$ \\
\hline Petiole canal leaf III & $\begin{array}{l}\text { Wide with } \\
\text { erect margin }\end{array}$ & $\begin{array}{l}\text { Wide with } \\
\text { erect margins }\end{array}$ & $\begin{array}{l}\text { Open with } \\
\text { margins } \\
\text { spreading }\end{array}$ & $\begin{array}{l}\text { Margins } \\
\text { overlapping }\end{array}$ & $\begin{array}{l}\text { Margins } \\
\text { overlapping }\end{array}$ \\
\hline Petiole margins & $\begin{array}{l}\text { Winged and } \\
\text { not clasping }\end{array}$ & $\begin{array}{l}\text { Winged and } \\
\text { not clasping } \\
\text { the } \\
\text { pseudostem }\end{array}$ & $\begin{array}{l}\text { Winged and } \\
\text { not clasping }\end{array}$ & $\begin{array}{l}\text { Winged and } \\
\text { clasping the } \\
\text { pseudostem }\end{array}$ & $\begin{array}{l}\text { Winged and } \\
\text { clasping the } \\
\text { pseudostem }\end{array}$ \\
\hline Wing type & Dry & Dry & Dry & Dry & Dry \\
\hline
\end{tabular}




\begin{tabular}{|c|c|c|c|c|c|}
\hline Petiole margin colour & Light brown & $\begin{array}{l}\text { Pink-purple } \\
\text { to red }\end{array}$ & Green & Black-dark purple & $\begin{array}{l}\text { Dark purple to } \\
\text { black }\end{array}$ \\
\hline Edge of petiole margin & $\begin{array}{l}\text { With a colour } \\
\text { line along }\end{array}$ & $\begin{array}{l}\text { With a } \\
\text { colour line } \\
\text { along }\end{array}$ & $\begin{array}{l}\text { Colourless } \\
\text { (without a } \\
\text { colour line } \\
\text { along) }\end{array}$ & $\begin{array}{l}\text { With a colour line } \\
\text { along }\end{array}$ & $\begin{array}{l}\text { With a colour } \\
\text { line along }\end{array}$ \\
\hline $\begin{array}{l}\text { Petiole margin width } \\
(\mathrm{cm})\end{array}$ & $\leq 1 \mathrm{~cm}$ & $\leq 1 \mathrm{~cm}$ & $\leq 1 \mathrm{~cm}$ & $\leq 1 \mathrm{~cm}$ & $\leq 1 \mathrm{~cm}$ \\
\hline Leaf blade length $(\mathrm{cm})$ & $\leq 150 \mathrm{~cm}$ & $\leq 150 \mathrm{~cm}$ & $171-220 \mathrm{~cm}$ & $171-220 \mathrm{~cm}$ & $151-170 \mathrm{~cm}$ \\
\hline Leaf blade width (cm) & $\leq 50 \mathrm{~cm}$ & $\leq 50 \mathrm{~cm}$ & $\leq 50 \mathrm{~cm}$ & $51-60 \mathrm{~cm}$ & $51-60 \mathrm{~cm}$ \\
\hline Petiole length $(\mathrm{cm})$ & $51-70 \mathrm{~cm}$ & $31-50 \mathrm{~cm}$ & $51-70 \mathrm{~cm}$ & $51-70 \mathrm{~cm}$ & $51-70 \mathrm{~cm}$ \\
\hline $\begin{array}{l}\text { Colour of leaf upper } \\
\text { surface }\end{array}$ & Green-yellow & Green-yellow & Green & $\begin{array}{l}\text { Dark green with } \\
\text { red-purple }\end{array}$ & Dark green \\
\hline $\begin{array}{l}\text { Appearance of leaf } \\
\text { upper surface }\end{array}$ & Dull & Shiny & Shiny & Shiny & Shiny \\
\hline $\begin{array}{l}\text { Colour of leaf lower } \\
\text { surface }\end{array}$ & Green-yellow & Green-yellow & Medium green & Green & Medium green \\
\hline $\begin{array}{l}\text { Appearance of leaf } \\
\text { lower surface }\end{array}$ & Dull & Dull & Dull & Dull & Dull \\
\hline Wax on leaves & $\begin{array}{l}\text { Very little or } \\
\text { no visible sign } \\
\text { of wax }\end{array}$ & Few wax & $\begin{array}{l}\text { Moderately } \\
\text { waxy }\end{array}$ & Few wax & $\begin{array}{l}\text { Moderately } \\
\text { waxy }\end{array}$ \\
\hline $\begin{array}{l}\text { Insertion point of } \\
\text { blades on petiole }\end{array}$ & Symmetric & Assymetric & Symmetric & Symmetric & Assymetric \\
\hline Shape of leaf base & $\begin{array}{l}\text { Both sides } \\
\text { pointed }\end{array}$ & $\begin{array}{l}\text { Both sides } \\
\text { pointed }\end{array}$ & $\begin{array}{l}\text { Both sides } \\
\text { pointed }\end{array}$ & Both side rounded & $\begin{array}{l}\text { Both side } \\
\text { rounded }\end{array}$ \\
\hline Leaf corrugation & $\begin{array}{l}\text { Very } \\
\text { corrugated }\end{array}$ & $\begin{array}{l}\text { Very } \\
\text { corrugated }\end{array}$ & $\begin{array}{l}\text { Very } \\
\text { corrugated }\end{array}$ & Very corrugated & $\begin{array}{l}\text { Very } \\
\text { corrugated }\end{array}$ \\
\hline $\begin{array}{l}\text { Colour of midrib dorsal } \\
\text { surface }\end{array}$ & Light green & Light green & Green & Green & Light green \\
\hline $\begin{array}{l}\text { Colour of midrib ventral } \\
\text { surface }\end{array}$ & Light green & Yellow & Light green & Green-purple & Light green \\
\hline $\begin{array}{l}\text { Colour of cigar leaf } \\
\text { dorsal surface }\end{array}$ & Green & Green & Green & Red-purple & Green \\
\hline $\begin{array}{l}\text { Blotches on leaves of } \\
\text { water suckers }\end{array}$ & $\begin{array}{l}\text { Without } \\
\text { blotches }\end{array}$ & $\begin{array}{l}\text { Without } \\
\text { blotches }\end{array}$ & $\begin{array}{l}\text { Without } \\
\text { blotches }\end{array}$ & Without blotches & $\begin{array}{l}\text { Without } \\
\text { blotches }\end{array}$ \\
\hline Peduncle length (cm) & $\begin{array}{l}\leq 30 \mathrm{~cm}(18 \\
\mathrm{cm})\end{array}$ & $\leq 30 \mathrm{~cm}$ & $\leq 30 \mathrm{~cm}$ & $31-60 \mathrm{~cm}$ & $31-60 \mathrm{~cm}$ \\
\hline $\begin{array}{l}\text { Empty nodes on } \\
\text { peduncle }\end{array}$ & 3 & 2 & 1 & 3 & \\
\hline Peduncle width (cm) & $\leq 6 \mathrm{~cm}(2.6)$ & $\leq 6 \mathrm{~cm}$ & $\leq 6 \mathrm{~cm}$ & $7-12 \mathrm{~cm}$ & $\leq 6 \mathrm{~cm}$ \\
\hline Peduncle colour & Light green & $\begin{array}{l}\text { Light green } \\
\text { with rusty } \\
\text { brown spots }\end{array}$ & Green & Dark green & Dark green \\
\hline Peduncle hairiness & $\begin{array}{l}\text { Very hairy, } \\
\text { short hairs }\end{array}$ & Hairless & Slightly hairy & Slightly hairy & Slightly hairy \\
\hline Bunch position & Horizontal & Horizontal & Horizontal & $\begin{array}{l}\text { Hanging at angle } \\
45^{\circ}\end{array}$ & $\begin{array}{l}\text { Hanging at } \\
\text { angle } 45^{\circ}\end{array}$ \\
\hline Bunch shape & Spiral & Spiral & Assymetric & $\begin{array}{l}\text { Truncated cone } \\
\text { shape }\end{array}$ & Assymetric \\
\hline Bunch appearance & Lax & Lax & Compact & Very compact & Compact \\
\hline $\begin{array}{l}\text { Flowers that form the } \\
\text { fruit }\end{array}$ & $\begin{array}{l}\text { Hermaphrodite } \\
\text { (presence of } \\
\text { pollen sacs and } \\
\text { pollens) }\end{array}$ & $\begin{array}{l}\text { Hermaphrodi } \\
\text { te (presence } \\
\text { of pollen sacs } \\
\text { and pollens) }\end{array}$ & $\begin{array}{l}\text { Hermaphrodite } \\
\text { (presence of } \\
\text { pollen sacs and } \\
\text { pollens) }\end{array}$ & $\begin{array}{l}\text { Hermaphrodite } \\
\text { (presence of } \\
\text { pollen sacs and } \\
\text { pollens) }\end{array}$ & $\begin{array}{l}\text { Hermaphrodite } \\
\text { (presence of } \\
\text { pollen sacs and } \\
\text { pollens) }\end{array}$ \\
\hline Fruits & Biseriate & Biseriate & Biseriate & Biseriate & Biseriate \\
\hline Rachis type & Present & Present & Present & Present & Present \\
\hline Rachis position & $\begin{array}{l}\text { Falling } \\
\text { vertically }\end{array}$ & Horizontal & Horizontal & At an angle & At an angle \\
\hline Rachis appearance & Bare & Bare & $\begin{array}{l}\text { Neutral } \\
\text { flowers (one to } \\
\text { few hands }\end{array}$ & $\begin{array}{l}\text { Neutral flowers } \\
\text { (one to few hands } \\
\text { only, stalk is bare }\end{array}$ & $\begin{array}{l}\text { Neutral } \\
\text { flowers (one to } \\
\text { few hands }\end{array}$ \\
\hline
\end{tabular}




\begin{tabular}{|c|c|c|c|c|c|}
\hline & & & $\begin{array}{l}\text { only, stalk is } \\
\text { bare below) }\end{array}$ & below) & $\begin{array}{l}\text { only, stalk is } \\
\text { bare below) }\end{array}$ \\
\hline Male bud type & $\begin{array}{l}\text { Normal } \\
\text { (present) }\end{array}$ & $\begin{array}{l}\text { Normal } \\
\text { (present) }\end{array}$ & $\begin{array}{l}\text { Normal } \\
\text { (present) }\end{array}$ & Normal (present) & $\begin{array}{l}\text { Normal } \\
\text { (present) }\end{array}$ \\
\hline Male bud shape & Like a top & Like a top & Like a top & Rounded & Rounded \\
\hline Male bud size $(\mathrm{cm})$ & $\begin{array}{l}\text { Diam: } 5.1 ; \\
\text { Length: } 12.2\end{array}$ & $\begin{array}{l}\text { Not } \\
\text { observed }\end{array}$ & $\begin{array}{l}\text { Diam: } 5.8 \\
\text { Length: } 8.2\end{array}$ & Not observed & Not observed \\
\hline Bract base shape & Large shoulder & $\begin{array}{l}\text { Large } \\
\text { shoulder }\end{array}$ & Large shoulder & Small shoulder & Small shoulder \\
\hline Bract apex shape & $\begin{array}{l}\text { Slightly } \\
\text { pointed }\end{array}$ & $\begin{array}{l}\text { Slighlty } \\
\text { pointed }\end{array}$ & Pointed & Obtuse and split & $\begin{array}{l}\text { Obtuse and } \\
\text { split }\end{array}$ \\
\hline Bract imbrication & $\begin{array}{l}\text { Old bracts } \\
\text { overlap at apex } \\
\text { of bud }\end{array}$ & $\begin{array}{l}\text { Old bracts } \\
\text { overlap at } \\
\text { apex of bud }\end{array}$ & $\begin{array}{l}\text { Old bracts } \\
\text { overlap at apex } \\
\text { of bud }\end{array}$ & $\begin{array}{l}\text { Young bracts } \\
\text { slightly overlap }\end{array}$ & $\begin{array}{l}\text { Young bracts } \\
\text { slightly overlap }\end{array}$ \\
\hline $\begin{array}{l}\text { Colour of the bract } \\
\text { external face }\end{array}$ & Red-purple & Red-purple & Yellow & Red-purple & Purple \\
\hline $\begin{array}{l}\text { Colour of the bract } \\
\text { internal face }\end{array}$ & Red & Orange red & $\begin{array}{l}\text { Yellow or } \\
\text { green }\end{array}$ & Red & Red \\
\hline $\begin{array}{l}\text { Colour on the bract } \\
\text { apex }\end{array}$ & $\begin{array}{l}\text { Not tinted } \\
\text { with yellow }\end{array}$ & $\begin{array}{l}\text { Not tinted } \\
\text { with yellow }\end{array}$ & $\begin{array}{l}\text { Colour is } \\
\text { uniform yellow } \\
\text { until apex }\end{array}$ & Tinted with yellow & $\begin{array}{l}\text { Tinted with } \\
\text { yellow }\end{array}$ \\
\hline Colour stripes on bract & $\begin{array}{l}\text { Without } \\
\text { discoloured } \\
\text { lines }\end{array}$ & $\begin{array}{l}\text { Without } \\
\text { discoloured } \\
\text { lines }\end{array}$ & $\begin{array}{l}\text { Without } \\
\text { discoloured } \\
\text { lines }\end{array}$ & $\begin{array}{l}\text { Without } \\
\text { discoloured lines }\end{array}$ & $\begin{array}{l}\text { Without } \\
\text { discoloured } \\
\text { lines }\end{array}$ \\
\hline Bract scars on rachis & $\begin{array}{l}\text { Very } \\
\text { prominent }\end{array}$ & $\begin{array}{l}\text { Very } \\
\text { prominent }\end{array}$ & $\begin{array}{l}\text { Very } \\
\text { prominent }\end{array}$ & Not prominent & Not prominent \\
\hline $\begin{array}{l}\text { Fading of colour on } \\
\text { bract base }\end{array}$ & $\begin{array}{l}\text { Colour } \\
\text { discontinuing } \\
\text { towards the } \\
\text { base }\end{array}$ & $\begin{array}{l}\text { Colour } \\
\text { discontinuing } \\
\text { towards the } \\
\text { base }\end{array}$ & $\begin{array}{l}\text { Colour } \\
\text { homogenous } \\
\text { yellow }\end{array}$ & $\begin{array}{l}\text { Colour } \\
\text { homogenous }\end{array}$ & $\begin{array}{l}\text { Colour } \\
\text { homogenous }\end{array}$ \\
\hline Male bract shape & $\begin{array}{l}\mathrm{x} / \mathrm{y}<0.28 \\
\text { (Lanceolate) }\end{array}$ & $\begin{array}{l}x / y<0.28 \\
\text { (Lanceolate) }\end{array}$ & $\begin{array}{l}\mathrm{x} / \mathrm{y}<0.28 \\
\text { (Lanceolate) }\end{array}$ & $\begin{array}{l}x / y>0.30 \\
\text { (Ovate) }\end{array}$ & $\begin{array}{l}x / y>0.30 \\
\text { (Ovate) }\end{array}$ \\
\hline Male bract lifting & $\begin{array}{l}\text { Lifting two or } \\
\text { more at a time }\end{array}$ & $\begin{array}{l}\text { Lifting one at } \\
\text { a time }\end{array}$ & $\begin{array}{l}\text { Lifting two or } \\
\text { more at a time }\end{array}$ & $\begin{array}{l}\text { Lifting two or } \\
\text { more at a time }\end{array}$ & $\begin{array}{l}\text { Lifting two or } \\
\text { more at a time }\end{array}$ \\
\hline $\begin{array}{l}\text { Bract behaviour before } \\
\text { falling }\end{array}$ & Revolute & Revolute & Revolute & Not revolute & Not revolute \\
\hline Wax on the bract & Very few wax & Very few wax & Very few wax & Very waxy & Very waxy \\
\hline $\begin{array}{l}\text { Presence of grooves on } \\
\text { the bract }\end{array}$ & $\begin{array}{l}\text { Moderate } \\
\text { grooving }\end{array}$ & $\begin{array}{l}\text { Moderate } \\
\text { grooving }\end{array}$ & $\begin{array}{l}\text { Moderate } \\
\text { grooving }\end{array}$ & Few grooves & Few grooves \\
\hline Male flower behaviour & $\begin{array}{l}\text { Falling before } \\
\text { the bract }\end{array}$ & $\begin{array}{l}\text { Falling } \\
\text { before the } \\
\text { bract }\end{array}$ & $\begin{array}{l}\text { Falling before } \\
\text { the bract }\end{array}$ & $\begin{array}{l}\text { Falling before the } \\
\text { bract }\end{array}$ & $\begin{array}{l}\text { Falling before } \\
\text { the bract }\end{array}$ \\
\hline $\begin{array}{l}\text { Compound tepal basic } \\
\text { colour }\end{array}$ & Cream & Cream & Cream & Cream & Cream \\
\hline $\begin{array}{l}\text { Compound tepal } \\
\text { pigmentation }\end{array}$ & $\begin{array}{l}\text { Rust coloured } \\
\text { spots }\end{array}$ & $\begin{array}{l}\text { Very few or } \\
\text { no visible } \\
\text { sign of } \\
\text { pigmentation }\end{array}$ & $\begin{array}{l}\text { Rust coloured } \\
\text { spots }\end{array}$ & Presence of pink & $\begin{array}{l}\text { Presence of } \\
\text { pink }\end{array}$ \\
\hline $\begin{array}{l}\text { Lobe colour of } \\
\text { compound tepal }\end{array}$ & Yellow & Cream & Yellow & Yellow & Yellow \\
\hline Free tepal colour & $\begin{array}{l}\text { Tinted with } \\
\text { yellow }\end{array}$ & $\begin{array}{l}\text { Translucent } \\
\text { white }\end{array}$ & $\begin{array}{l}\text { Tinted with } \\
\text { yellow }\end{array}$ & Tinted with pink & $\begin{array}{l}\text { Tinted with } \\
\text { yellow }\end{array}$ \\
\hline Free tepal shape & Oval & Oval & Oblong & Oval & Oval \\
\hline Free tepal appearance & $\begin{array}{l}\text { Several folding } \\
\text { under apex } \\
\text { (corrugated) }\end{array}$ & $\begin{array}{l}\text { Several } \\
\text { folding under } \\
\text { apex } \\
\text { (corrugated) }\end{array}$ & $\begin{array}{l}\text { Several folding } \\
\text { under apex } \\
\text { (corrugated) }\end{array}$ & $\begin{array}{l}\text { More or less } \\
\text { smooth }\end{array}$ & $\begin{array}{l}\text { More or less } \\
\text { smooth }\end{array}$ \\
\hline Free tepal apex shape & Triangular & Thread-like & Thread-like & Triangular & Thread-like \\
\hline Anthers exsertion & Same level & Exserted & Exserted & Exserted & Exserted \\
\hline Filament colour & Cream & Cream & Cream & Cream & Cream \\
\hline Anther colour & Cream & Cream & Cream & Cream & Cream \\
\hline
\end{tabular}




\begin{tabular}{|c|c|c|c|c|c|}
\hline Pollen sac colour & $\begin{array}{l}\text { Brown/ rusty } \\
\text { brown }\end{array}$ & $\begin{array}{l}\text { Brown/rusty } \\
\text { brown }\end{array}$ & $\begin{array}{l}\text { Brown/rusty } \\
\text { brown }\end{array}$ & Cream & $\begin{array}{l}\text { Cream to pale } \\
\text { brown }\end{array}$ \\
\hline Style basic colour & White to cream & Cream & Cream & Cream & Cream \\
\hline Pigmentation on style & $\begin{array}{l}\text { Without } \\
\text { pigmentation }\end{array}$ & $\begin{array}{l}\text { Without } \\
\text { pigmentation }\end{array}$ & $\begin{array}{l}\text { Without } \\
\text { pigmentation }\end{array}$ & Purple & $\begin{array}{l}\text { Without } \\
\text { pigmentation }\end{array}$ \\
\hline Style exsertion & Inserted & Same level & Same level & Same level & Same level \\
\hline Style shape & Straight & Straight & Straight & Staight & Staight \\
\hline Stigma colour & Orange & Yellow & Pale orange & Cream to yellow & Yellow \\
\hline Ovary shape & Arched & Arched & Arched & Straight & Straight \\
\hline Ovary basic colour & Cream & Yellow & Cream & Cream & Cream \\
\hline Ovary pigemtation & $\begin{array}{l}\text { Very few or no } \\
\text { visible sign of } \\
\text { pigmentation }\end{array}$ & $\begin{array}{l}\text { Very few or } \\
\text { no visible } \\
\text { sign of } \\
\text { pigmentation }\end{array}$ & $\begin{array}{l}\text { Very few or no } \\
\text { visible sign of } \\
\text { pigmentation }\end{array}$ & With red-purple & $\begin{array}{l}\text { With red- } \\
\text { purple }\end{array}$ \\
\hline $\begin{array}{l}\text { Dominant colour of } \\
\text { male flower }\end{array}$ & Cream & Cream & Cream & Cream & Cream \\
\hline Arrangement of ovules & Two rowed & Two rowed & Two rowed & Four rowed & Four rowed \\
\hline Fruit position & Curved upward & $\begin{array}{l}\text { Curved } \\
\text { upward }\end{array}$ & Curved upward & Curved upward & $\begin{array}{l}\text { Curved } \\
\text { upward }\end{array}$ \\
\hline Number of fruits & $13-16$ & $\leq 12$ & $\leq 12$ & $\leq 12$ & $13-16$ \\
\hline Fruit length (cm) & $<10$ & $<10$ & $10-15$ & $10-15$ & $10-15$ \\
\hline Fruit shape & $\begin{array}{l}\text { Curved (sharp } \\
\text { curve) }\end{array}$ & $\begin{array}{l}\text { Curved } \\
\text { (sharp curve) }\end{array}$ & $\begin{array}{l}\text { Curved (sharp } \\
\text { curve) }\end{array}$ & Straight & Straight \\
\hline $\begin{array}{l}\text { Transverse section of } \\
\text { fruit }\end{array}$ & Slightly ridged & $\begin{array}{l}\text { Slightly } \\
\text { ridged }\end{array}$ & Rounded & Pronounced ridges & Slightly ridged \\
\hline Fruit apex & $\begin{array}{l}\text { Lengthily } \\
\text { pointed }\end{array}$ & $\begin{array}{l}\text { Bottle } \\
\text { necked }\end{array}$ & Bottle necked & Pointed & Pointed \\
\hline $\begin{array}{l}\text { Remains of flower } \\
\text { relicts }\end{array}$ & $\begin{array}{l}\text { Base of style } \\
\text { prominent }\end{array}$ & $\begin{array}{l}\text { Base of the } \\
\text { style } \\
\text { prominent }\end{array}$ & $\begin{array}{l}\text { Without any } \\
\text { floral relicts }\end{array}$ & $\begin{array}{l}\text { Without any floral } \\
\text { relicts }\end{array}$ & $\begin{array}{l}\text { Without any } \\
\text { floral relicts }\end{array}$ \\
\hline $\begin{array}{l}\text { Fruit pedicel length } \\
(\mathrm{mm})\end{array}$ & $\leq 10 \mathrm{~mm}$ & $\leq 10 \mathrm{~mm}$ & $11-20 \mathrm{~mm}$ & $\geq 21 \mathrm{~mm}$ & $\geq 21 \mathrm{~mm}$ \\
\hline $\begin{array}{l}\text { Fruit pedicel width } \\
(\mathrm{mm})\end{array}$ & 5 to $10 \mathrm{~mm}$ & 5 to $10 \mathrm{~mm}$ & 5 to $10 \mathrm{~mm}$ & $>10 \mathrm{~mm}$ & $>10 \mathrm{~mm}$ \\
\hline Pedicel surface & Hairless & Hairless & Hairless & Hairless & Hairless \\
\hline $\begin{array}{l}\text { Immature fruit peel } \\
\text { colour }\end{array}$ & Light green & Light green & Light green & Dark green & Light green \\
\hline Mature fruit peel colour & Not observed & Bright yellow & Bright yellow & Yellow to orange & Black \\
\hline Fruit peel thickness & Not observed & Two or less & Two or less & Three or more & Three or more \\
\hline Cracks in fruit peel & Not observed & Cracked & Cracked & Without cracks & Without cracks \\
\hline $\begin{array}{l}\text { Pulp colour before } \\
\text { maturity }\end{array}$ & White to cream & Cream & Cream & White to cream & White \\
\hline Pulp colour at maturity & Not observed & $\begin{array}{l}\text { Ivory to } \\
\text { yellow }\end{array}$ & Ivory to yellow & Cream to ivory & Cream \\
\hline Fruits fall from hands & Not observed & Persistent & Decidous & Persistent & Persistent \\
\hline Flesh texture & Not observed & Soft & Soft & Soft & Soft \\
\hline Predominant taste & Not observed & Sugary & Sweet & Sweet and acidic & $\begin{array}{l}\text { Sweet and } \\
\text { acidic }\end{array}$ \\
\hline $\begin{array}{l}\text { Presence of seeds with } \\
\text { source of pollen }\end{array}$ & Not observed & $>20$ & $>20$ & $>20$ & $>20$ \\
\hline Seed surface & Not observed & Wrinkled & Wrinkled & Slightly wrinkled & $\begin{array}{l}\text { Slightly } \\
\text { wrinkled }\end{array}$ \\
\hline Seed shape & Not observed & $\begin{array}{l}\text { Angular } \\
\text { (more or less } \\
\text { pyramidal) }\end{array}$ & $\begin{array}{l}\text { Angular (more } \\
\text { or less } \\
\text { pyramidal) }\end{array}$ & $\begin{array}{l}\text { Rounded (but not } \\
\text { completely } \\
\text { spherical) }\end{array}$ & $\begin{array}{l}\text { Rounded (but } \\
\text { not completely } \\
\text { spherical) }\end{array}$ \\
\hline Seed colour & Not observed & Brown-black & Dark brown & Brown & Dark brown \\
\hline
\end{tabular}

Deforestation and forests fragmentations has caused major concerns on the lost of genetic resources including Musa, so that we have to conserve in ex situ collections more for the wild ones before it finally become extinct. The important role of an ex situ conservation of Musa germplasm are providing longterm and sustainable conservation of Musa genetic resources, main- 
taining a source of genetic diversity and related information in the public domain, contributing to better understanding Musa diversity through characterization, evaluation and documentation, providing a service for the safe movement of germplasm and related information and developing and transferring ex situ conservation technologies [26]. Further conservation efforts; an effective monitoring and cultivation management strategy, including adequate measures or actions to eliminate both abiotic and biotic stresses particularly for the viral diseases are extremely required to keep this Musa germplasms continuously conserved and preserved for future.

\section{CONCLUSION}

About 17 wild Musa accessions have been recorded planted in Purwodadi Botanic Garden since 1990 until 2012 but only 8 living accessions remained in 2012. Through observations to its differentiating morphological characteristics of those 8 living Musa specimens revealed that some of them are not true to its type and one species has been determined its species level so that their registration identity needs to be revised. Accessions number XXIV.D. 26-a (Figure 2-a) was not true to Musa acuminata var. tomentosa, while XXIV.D.27 (Figure 2-b) and XXIV.D.30-a (Figure 2-c) were not true to Musa acuminata var. rutilifes, their differentiating morphological characteristics were resembled Musa acuminata cultivars. One unidentified spesies (Musa sp.) accession XXIV.A.27 have been determined, its morphological characteristics quite close resembled to Musa acuminata var. alasensis.

Three distinct varieties of $M$. acuminata i.e. alasenis, rutilifes and flava; and two distinct forms of M. balbisiana i.e. Pisang Klutuk Wulung and Klutuk Ijo have been reviewed its morphotaxonomic. The distinguishing characteristics of each variety are shown in Table 2. Deforestation and forests fragmentations has caused major concerns on the lost of genetic resources including Musa, so that it is important next to prioritize ex-situ conservation of wild Musa species not yet collected in Purwodadi Botanic Garden especially from Eastern Indonesia.

\section{ACKNOWLEDGEMENT}

The author would like to acknowledge Indonesian Institute of Sciences through DIPA funds for funding this research project; also greatly appreciates to Ahmad Masrum, Jafar and Lamiran for all the assitances, helps and supports during the study at Musa germplasm collections - Purwodadi Botanic Garden.

\section{REFERENCES}

1. Simmonds NW (1959) Bananas. Longman Inc. New York.

2. Espino RRC, Jamaludin SH, Silayoi B, Nasution RE (1992) Musa L. (edible cultivars), in Verheij, E.W.M. and R.E. Coronel (eds.). Plant Resources of South-East Asia No.2, Edible fruits and nuts. Prosea Foundation. Bogor.

3. Valmayor RV (2001) Classification and characterization of Musa exotica, $M$. alinsanaya, and M. acuminata ssp. Errans. Infomusa 10(2): 35-39

4. Nasution RE (1991) A taxonomic study of the species Musa acuminata Colla with its intraspecific taxa in Indonesia. Memoirs of Tokyo University of Agriculture 32: 1-122.

5. Cheesman EE (1947) Classification of the bananas II, The genus Musa L. Kew Bull. 2: 106117

6. Simmonds NW, Weatherup STC (1990) Numerical taxonomy of the wild bananas (Musa). New Phytol. 118: 567-571.

7. Häkkinen M (2004) Musa campestris Becc. (Musaceae) varieties in Northern Borneo. Folia Malaysiana 5 (2): 81-100

8. Häkkinen M (2009) Lectotypification of two Musa sections (Musaceae). Nordic Journal of Botany 27: 207-209

9. Singh HP, Uma S, Sathiamoorthy S (2001) A tentative key for identification and classification of Indian bananas. National Research Centre for Banana (ICAR). Tiruchirapalli.

10. Argent GCG (1976) The wild bananas of Papua New Guinea, Notes Roy. Bot.Gard.Edinb. 35 (1):77-114.

11. Hapsari L (2011) Dua dasawarsa koleksi Pisang (Musaceae) Kebun Raya Purwodadi (1990-2010). Jurnal Berkala Penelitian Hayati Edisi Khusus 5A: 147-151

12. Hapsari L (2011) Indonesian Banana Cultivars Purwodadi Botanic Garden's Collection. In Proceeding of International Conference on Food Safety \& Food Security, 1 - 2 Dec 2010. Gadjah Mada University. Jogjakarta.

13. Hapsari L (2012) Laporan kegiatan tematik: Revitalisasi koleksi dan kajian keanekaragaman Musaceae dan Dioscoreaceae di Kebun Raya Purwodadi, UPT Balai Konservasi Tumbuhan Kebun Raya Purwodadi, Pasuruan (Unpublished)

14. Nasution RE, Yamada I (2001) Pisang-Pisang liar di Indonesia. Puslitbang Biologi-LIPI. Bogor.

15. IPGRI-INIBAP/CIRAD (1996) Descriptors for banana (Musa spp.). International Plant Genetic Resources Institute (IPGRI). Maccarese. 
16. Backer CA, Van Den Brink RCB (1968), Flora of Java Vol. III. Wolters. Noordhoff NV. Groningen.

17. Sundararaj D, Balasubramanyam G (1971) Occurrence of Musa ornata Roxb. in South India. Kew. Bull. 25 (2): 331-333.

18. The Plant List (2013) A working list of all plant species. http://www.theplantlist.org/. Accessed date: January 7, 2013.

19. Häkkinen M, Väre H, Christenhusz MJM (2012) Identity of a Pisang - historical concepts of Musa (Musaceae) and the reinstatement of Musa troglodytarum, Folia Malaysiana 13(2): 1-14

20. Cheesman EE (1950) Classification of the bananas III, Critical notes on species, Musa borneensis Beccari. Kew Bull. 2: 151-52.

21. Beccarii O (1902) Nota sui namami selvatici di Borneo, in Nelle Foreste di Borneo. Tipografia di Salvadore Landi. Firenze.
22. Häkkinen M, Meekiong K (2005) Musa borneensis Becc. (Musaceae) and its intraspecific taxa in Borneo. APG Acta Phytotax. Geobot. 56 (3): 213230

23. Daniels J, Jenny C, Karamura D, Tomekpe K (2001) Musalogue: A catalogue of Musa germplasm. Diversity in the genus Musa (E. Arnaud \& S. Sharrock, compil). International Network for the Improvement of Banana and Plantain. Montpellier.

24. Ridley HN (1893) On the flora of the Eastern Coast of the Malay Peninsula. Trans. Linn. Soc. London (Bot.): 385-386.

25. Backer CA (1924) Musaceae, in Flora van Java AFL.3. Druikkerijen Ruygrok \& Co. Batavia.

26. INIBAP (2002) A Strategy for the global Musa genomics consortium. international network for the improvement of banana and plaintain. Report of a meeting held in Arlington, USA. 17-20 Jul 2001. IPGRI. Maccarese. 